\title{
Simultaneous Determination of Ten Flavonoids from Viscum coloratum Grown on Different Host Species and Different Sources by LC-MS
}

\author{
Yunli ZhaO, ${ }^{a, b}$ Zhiguo Yu, ${ }^{a}$ Ronghua Fan, ${ }^{a}$ Xiaoxia GaO, ${ }^{c}$ Miao Yu, ${ }^{a}$ Hongyan Li, ${ }^{b}$ \\ Hongjun $\mathrm{WEI}^{,}$and Kaishun $\mathrm{BI}^{*}, a$ \\ ${ }^{a}$ Department of Pharmaceutical Analysis, Shenyang Pharmaceutical University; Wenhua Road 103, Shenyang 110016 \\ P. R. China: ${ }^{b}$ Pharmaland Technology Development Co., Ltd.; Tianjin Economic Technological Development Area, Tianjin \\ 300457, P. R. China: and ${ }^{c}$ Modern Research Center for Traditional Chinese Medicine, Shanxi University; Wucheng Road \\ 92, Taiyuan, 030006, P. R. China. Received May 21, 2011; accepted August 25, 2011; published online September 1, 2011
}

\begin{abstract}
A high-performance liquid chromatographic-mass spectrometric method was developed for the simultaneous determination of 10 flavonoids in Viscum coloratum obtained from different host species and different sources. Viscum coloratum was extracted with $50 \%$ methanol. The extracts were separated on a $\mathrm{C}_{18}$ column with a gradient of $0.1 \%(v / v)$ formic acid and methanol. The flavonoids in the extracts were detected by negative electrospray ionization mass spectrometry in selective ion monitoring mode. The calibration curves showed good linearity $(r>0.998)$ within the test ranges (homoeriodictyol: $0.149-8.940 \mu \mathrm{g} / \mathrm{ml}$, homoeriodictyol-7-O- $\beta$-D-glycoside: $0.230-13.80 \mu \mathrm{g} / \mathrm{ml}$, homoeriodictyol-7- $O$ - $\beta$-D-apiose $(1 \rightarrow 2)-\beta$-D-glycoside: $5.000-300.0 \mu \mathrm{g} / \mathrm{ml}$, homoeriodictyol-7- $O$ - $\beta$-D-apiose $(1 \rightarrow 5)$ - $\beta$-D-apiose $(1 \rightarrow 2)$ - $\beta$-D-glycoside: $0.835-125.3 \mu \mathrm{g} / \mathrm{ml}$, rhamnazin-3-O- $\beta$-D-glucoside: $0.064-3.840 \mu \mathrm{g} / \mathrm{ml}$, rhamnazin-3- $O-\beta$-D-(6"- $\beta$-hydroxy- $\beta$-methyglutaryl)-glucoside: $1.435-86.10 \mu \mathrm{g} / \mathrm{ml}$, isorhamnetin-3- $O$ - $\beta$-D-glucoside: $0.930-55.80 \mu \mathrm{g} / \mathrm{ml}, 5$-hydroxy-3,7,3' -trimethoxyflavone-4' $O$ - $\beta$-D-glucoside: $0.067-4.020$ $\mu \mathrm{g} / \mathrm{ml}, 5,7,4^{\prime}$-trihydroxy-3,3'-dimethoxyflavone: $0.270-16.20 \mu \mathrm{g} / \mathrm{ml}$, pachypodol: $\left.0.110-6.600 \mu \mathrm{g} / \mathrm{ml}\right)$. The limits of quantification were between $0.006-0.720 \mu \mathrm{g} / \mathrm{ml}$. The assay was reproducible and the overall intra- and interday variations were less than $4.6 \%$. The recoveries varied from 93.4 to $103.9 \%$ at three different concentration levels. The validation method was used to determine the contents of 10 flavonoids in Viscum coloratum. A oneway analysis of variance was applied to evaluate Viscum coloratum-host-source interactions. Compared with the host species, the sample source had a significant impact on the sample content.
\end{abstract}

Key words Viscum coloratum; determination; flavonoid; HPLC-MS

Viscum coloratum (Ком.) NAKAI ( $V$. coloratum) is a perennial evergreen, semi-parasitic plant which grows on branches or stems of deciduous trees. It is known as Hujisheng in Chinese. ${ }^{1)} V$. coloratum is an important medicinal herb which has been used in various treatments such as cardiovascular diseases, cancer, hepatitis and hemorrhage. ${ }^{2,3)}$ It was the main ingredient in many formulae such as hujisheng injection, Huqi San, Hanbixiao keli etc. ${ }^{4-6)} V$. coloratum has been attracting more and more attention for its therapeutic effects. However, Traditional Chinese medicine is a complex system. An herbal medicine may consist of hundreds of constituents, and their contents vary depending on climate, regions of cultivation and seasons of harvest, which make it difficult to ensure the batch-to-batch uniformity. ${ }^{7}$ ) The quality control of standardized herbal extracts is essential for the therapeutic reproducibility, efficacy and safe application of extracts. Meanwhile, as a semi-parasitic plant, it is widely appreciated that the constituents of $V$. coloratum are not stable and depend not only on the biosynthesis pathway but also on the type of host plant. Therefore, host plant also is an influencing factor in the quality control of standardized herb extracts. But the ancient medical textbooks and Chinese pharmacopoeias do not give details of the host of $V$. coloratum. Luczkiewicz et al. have reported an HPLC method for comparative analysis of phenolic acids in Viscum album L. from various hosts. ${ }^{8)}$ They found that comparative chromatography revealed qualitative differences in the investigated compounds between the various plant materials. So in this paper we aim to control quality of $V$. coloratum through analyzing $V$. coloratum-host-source interactions.

The constituents of $V$. coloratum include flavonoids, alka- loids, triterpenoids, lignans, diarylheptanoids and essential oils. $^{2,9,10)} V$. coloratum is used in treatments of cardiovascular disease that is linked to the presence of flavonoids. ${ }^{11)}$ Homoeriodictyol (Hedt-I), homoeriodictyol-7- $O-\beta$-D-glycoside (Hedt-II), homoeriodictyol-7- $O$ - $\beta$-D-apiose $(1 \rightarrow 2)-\beta$-D-glycoside (Hedt-III), and homoeriodictyol-7- $O-\beta$-D-apiose $(1 \rightarrow$ $5)$ - $\beta$-D-apiose $(1 \rightarrow 2)$ - $\beta$-D-glycoside (Hedt-IV) are four dihydroflavones with anti-coagulant, ${ }^{12)}$ anti-inflammatory, ${ }^{13)}$ antioxidant, ${ }^{14)}$ anti-tumor ${ }^{15)}$ and anti-fungal activity. ${ }^{16)}$ Rhamnazin-3-O- $\beta$-D-glucoside (Rham-I), rhamnazin-3- $O-\beta$-D- $\left(6^{\prime \prime}-\right.$ $\beta$-hydroxy- $\beta$-methyglutaryl)-glucoside (Rham-II), isorhamnetin-3-O- $\beta$-D-glucoside (Isor), 5-hydroxy-3,7,3'-trimethoxyflavone-4'-O- $\beta$-D-glucoside (Httf), 5,7,4' -trihydroxy-3,3' dimethoxyflavone (Tddf) and pachypodol (Pach) are six favonols with the same effects. ${ }^{17-20)}$ Due to the importance of flavonoids, it could be considered as the 'marked compound' for the chemical evaluation or standardization of $V$. coloratum. To date, only a few studies of the quantitative determination of the flavonoids of $V$. coloratum using HPLC have been reported. ${ }^{21-23)}$ However, the constituents in $V$. coloratum are complex, and some of them usually in very low concentrations. Therefore, a more sensitive, selective method is required and the emergence of HPLC-MS makes this possible. It not only provides detailed structural information but also allows accurate and sensitive quantification of the multiple compounds present. For example, an HPLC-DAD-MS ${ }^{n}$ was developed for study of chemical and metabolic information of flavonoid extract of jujube seeds. This is of great importance in understanding the molecular mechanism of action and clinical effects of flavonoid extract of jujube seeds and facilitating further quantitative studies as well. ${ }^{24)}$ 
Table 1. Chemical Structures of 10 Flavonoids in V. coloratum

\begin{tabular}{|c|c|c|c|c|c|c|}
\hline & Marker component & Purity (\%) & Structure & $\mathrm{R}_{1}$ & $\mathrm{R}_{2}$ & $\mathrm{R}_{3}$ \\
\hline 1 & Hedt-I & 99.7 & & $-\mathrm{H}$ & - & - \\
\hline 2 & Hedt-II & 99.4 & & $-\beta$-D-Glc & - & - \\
\hline 3 & Hedt-III & 99.7 & & $-\beta$-D-Api-( $(\rightarrow 2)-\beta$-D-Glc & - & - \\
\hline 4 & Hedt-IV & 99.1 & & $\begin{array}{l}-\beta \text {-D-Api- }(1 \rightarrow 5)-\beta \text {-D-Api } \\
-(1 \rightarrow 2)-\beta \text {-D-Glc }\end{array}$ & - & - \\
\hline 5 & Rham-I & 99.2 & & $-\mathrm{CH}_{3}$ & $-\beta$-D-Glc & $-\mathrm{H}$ \\
\hline 6 & Rham-II & 98.3 & & $-\mathrm{CH}_{3}$ & $\begin{array}{r}\beta \text {-D- }\left(6^{\prime \prime}-\beta \text {-Hydroxy- } \beta \text { - }\right. \\
\text { methyglutaryl })-G l c\end{array}$ & $-\mathrm{H}$ \\
\hline 7 & Isor & 98.9 & & $-\mathrm{H}$ & $-\beta$-D-Glc & $-\mathrm{H}$ \\
\hline 8 & Httf & 98.1 & & $-\mathrm{CH}_{3}$ & $-\mathrm{CH}_{3}$ & $-\beta$-D-Glc \\
\hline 9 & Tddf & 98.7 & $\mathrm{OR}$ & $-\mathrm{H}$ & $-\mathrm{CH}_{3}$ & $-\mathrm{H}$ \\
\hline 10 & Pach & 99.0 & O & $-\mathrm{CH}_{3}$ & $-\mathrm{CH}_{3}$ & $-\mathrm{H}$ \\
\hline
\end{tabular}

In the present study, we aimed to develop and validate a sensitive and accurate HPLC-MS method for simultaneous determination of 10 flavonoids in $V$. coloratum, including Hedt-I (1), Hedt-II (2) Hedt-III (3), Hedt-IV (4), Rham-I (5), Rham-II (6), Isor (7), Httf (8), Tddf (9) and Pach (10). Their structures are listed in Table 1. During the method development, selective ion monitoring (SIM) was employed and an electrospray ionization source was operated in negative mode. V. coloratum growing on different host species and in different sources were determined using the developed method. A one-way analysis of variance was applied to evaluate $V$. coloratum-host-source interactions.

\section{Experimental}

Reagents and Standards Methanol was of HPLC grade (Fisher, U.S.A.). All other reagents were of analytical grade (Concord Tech Reagent Company, Tianjin, China). Deionized water was used throughout the study. The reference standards were isolated and purified in the laboratory from $V$. coloratum. The 10 flavonoids, Hedt-I, Hedt-II, Hedt-III, Hedt-IV, Rham-I, Rham-II, Isor, Httf, Tddf and Pach, were fully characterized using UV, NMR, MS, and the data compared with literature values. ${ }^{19,25-30)}$ The purities of standards are listed in Table 1 (measured by HPLC).

Plant Materials V. coloratum samples were collected from Changbai Mountain (CBM, Yanji, Jilin, China, temperate continental mountainous climate), Qian Mountain (QM, Anshan, Liaoning, China, warm temperate semi-humid continental monsoon climate), Xiyue Temple (XYT, Huayin, Shanxi, China, warm temperate semi-arid continental climate), Chengde Imperial Summer Resort (CISR, Chengde, Hebei, China, warm temperate semi-humid and semi-arid continental monsoon climate), Daqing Mountain (DQM, Bincounty, Heilongjiang, China, temperate semi-humid continental monsoon climate) and Xianxia Mountain (XXM, Quzhou, Zhejing, China, subtropical humid monsoon climate). The collected plant materials were dried at room temperature in a well-ventilated room without light. Dr. Qishi Sun authenticated the plant material, and the voucher specimens were deposited in the state Key Laboratory of Traditional Chinese Medicine (Shenyang Pharmaceutical University, China).

Apparatus and Operating Conditions The HPLC system consisted of a DGU-14 AM degasser, two Shimadzu 10ADvp Pumps, a high pressure mixer and a Shimadzu 10ATvp Autoinjector (Shimadzu, Kyoto, Japan). A Shimadzu 2010 liquid chromatograph-mass spectrometer (Shimadzu, Kyoto, Japan) equipped with an electrospray ionization (ESI) interface, and a Q-array-Octapole-Quadrupole mass analyzer (QoQ system) were used in the study.

Chromatographic separation of the extracts was performed on an ODS column (Synergi, $250 \mathrm{~mm} \times 4.6 \mathrm{~mm}$ i.d., particle size $4 \mu \mathrm{m}$, Phenomenex, U.S.A.), equipped with an ODS guard column (Security Guard, Phenomenex, U.S.A.). The mobile phase was $0.1 \%$ formic acid (A) and methanol (B). The gradient elution was: $0-20 \mathrm{~min}$, a linear gradient of $40-52 \% \mathrm{~B} ; 20-40 \mathrm{~min}$, a linear gradient of $52-80 \% \mathrm{~B}, 40-45 \mathrm{~min}, 80 \%$ $\mathrm{B}$; and then re-equilibrating the column with $40 \% \mathrm{~B}$ for $5 \mathrm{~min}$. The flow-rate

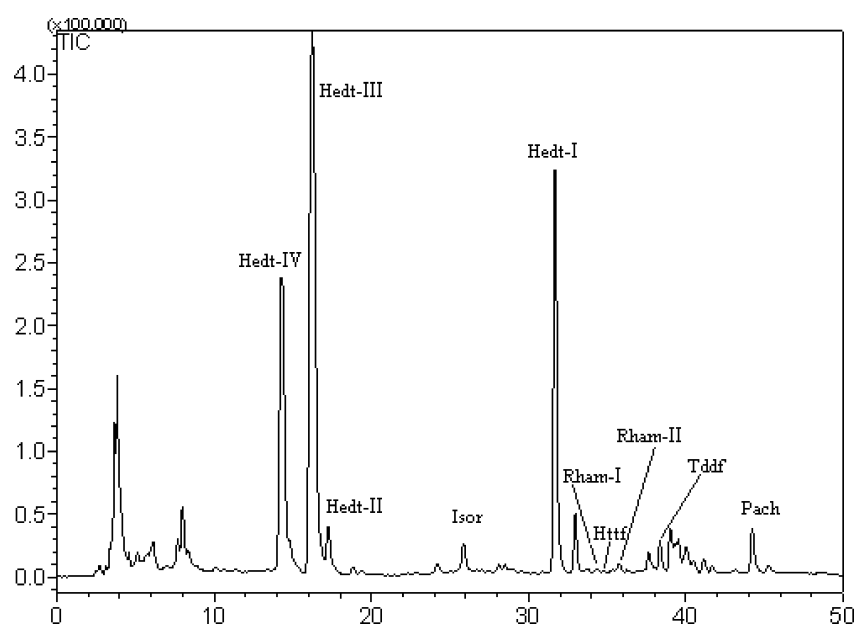

Fig. 1. TIC Chromatograms in Negative Ionization Mode of $V$. coloratum (Host Species: Acer monm MAXIM.)

was $0.8 \mathrm{ml} / \mathrm{min}$ (split ratio $1: 3$ ) and the column temperature was $30^{\circ} \mathrm{C}$.

Mass spectrometric conditions were optimized to obtain maximum sensitivity. The extracts were ionized in the negative ESI interface of the mass spectrometer. Mass spectra were obtained at a dwell time of $0.2 \mathrm{~s}$ in SIM mode and $1 \mathrm{~s}$ in scan mode. The curve dissolution line (CDL) voltage was fixed at $10.0 \mathrm{kV}$, the interface temperature was $400^{\circ} \mathrm{C}$, the CDL temperature was $200^{\circ} \mathrm{C}$, the heat block temperature was $200^{\circ} \mathrm{C}$, the detector voltage was $1.75 \mathrm{kV}$ and the nebulizing gas flow rate was $2.5 \mathrm{l} / \mathrm{min}$. The flavonoids were monitored at $m / z 301,463,595,727,491,635,477,551,329$ and 343 for Hedt-I, Hedt-II, Hedt-III, Hedt-IV, Rham-I, Rham-II, Isor, Httf, Tddf and Pach, respectively. Data collection, peak integration, and calculations were performed using LC-MS Solution Version 3.0 software.

Preparation of Standard Solutions Stock solutions of Hedt-I $(0.745$ $\mathrm{mg} / \mathrm{ml})$, Hedt-II $(0.460 \mathrm{mg} / \mathrm{ml})$, Hedt-III $(1.000 \mathrm{mg} / \mathrm{ml})$, Hedt-IV $(2.088 \mathrm{mg} /$ $\mathrm{ml})$, Rham-I $(0.320 \mathrm{mg} / \mathrm{ml})$, Rham-II $(1.435 \mathrm{mg} / \mathrm{ml})$, Isor $(0.930 \mathrm{mg} / \mathrm{ml})$, Httf $(0.335 \mathrm{mg} / \mathrm{ml})$, Tddf $(0.540 \mathrm{mg} / \mathrm{ml})$ and Pach $(0.220 \mathrm{mg} / \mathrm{ml})$ were prepared in methanol. Working standard solutions for calibration were prepared by diluting the stock solution with appropriate quantities of methanol. All working solutions were stored at $4^{\circ} \mathrm{C}$ and brought to room temperature before use.

Preparation of Sample Solutions V. coloratum samples were powdered in an electric blender and then passed through a \#4 mesh sieve. The powder was accurately weighed $(1.00 \mathrm{~g})$ in a round-bottom flask and $25 \mathrm{ml} 50 \%$ $(\mathrm{v} / \mathrm{v})$ methanol was added. The flask was then weighed accurately and heated in a water bath for $30 \mathrm{~min}$. The flask was then cooled and $50 \%$ methanol was added in order to compensate for the solvent loss. The extract was transferred to a centrifuge tube and centrifuged at $10000 \mathrm{rpm}$ for $5 \mathrm{~min}$. The supernatant was then passed through a membrane filter $(0.22 \mu \mathrm{m})$ prior to injection. 

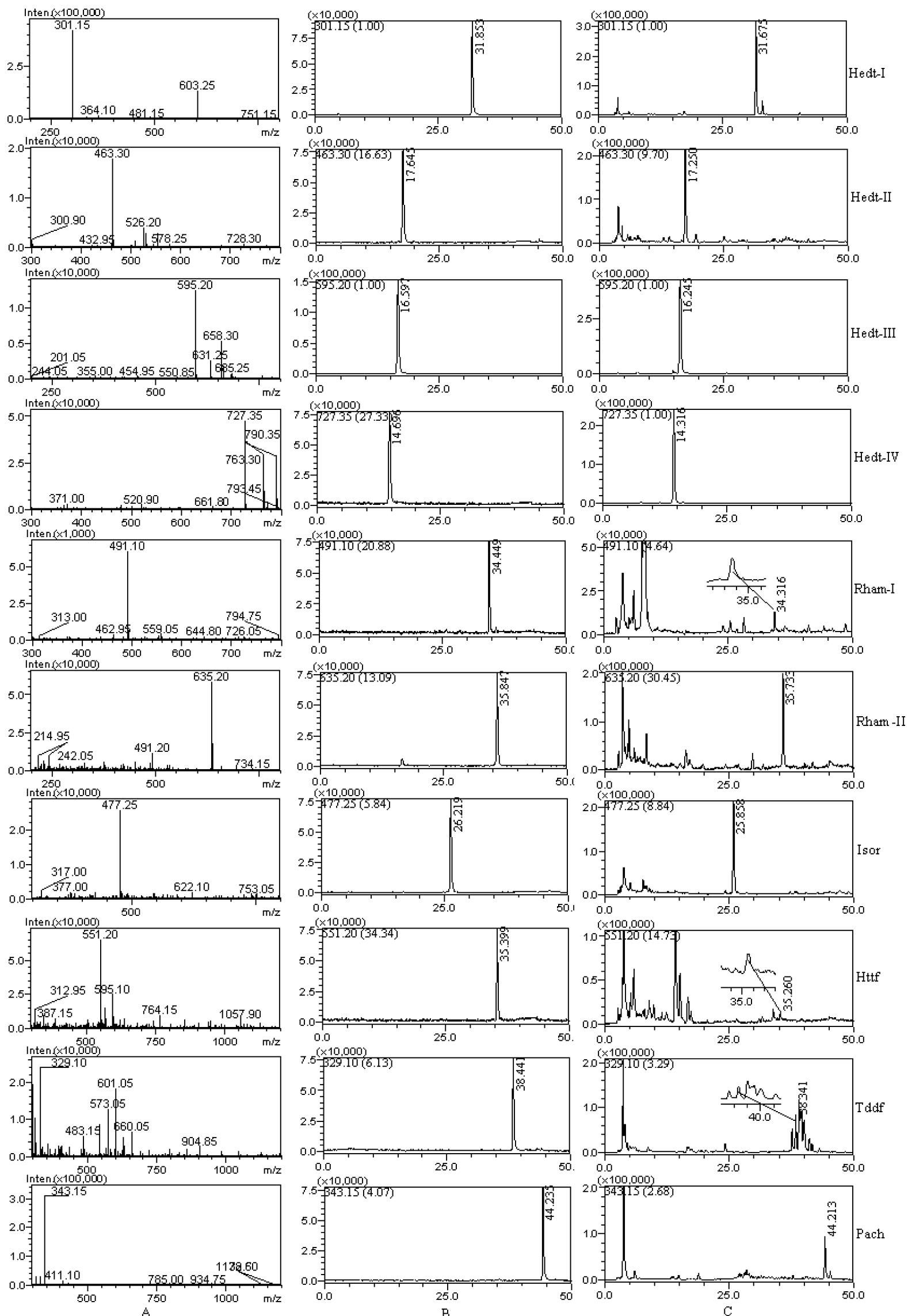

Fig. 2. (A) Mass Spectra of 10 Flavonoids Standard in Full Scan Mode; (B) Typical SIM Chromatograms of 10 Flavonoids Standard; (C) Typical SIM Chromatograms of 10 Flavonoids in V. coloratum (Host Species: Acer monm Maxim.) 


\section{Results and Discussion}

Optimization of LC-MS Conditions Since Pach has a low polarity compared with the other flavonoids, a different mobile phase with a different gradient elution of methanol-water or acetonitrile-water was tested. The results indicated that a mobile phase consisting of $0.1 \%$ aqueous formic acid-methanol with gradient elution provided high resolution for all the components in $V$. coloratum samples. The total ion current (TIC) chromatogram in negative ionization mode of a $V$. coloratum sample is shown in Fig. 1.

The 10 flavonoids were analyzed by MS in ESI negative ion mode without any problems. Full scan negative ion mass spectra (Fig. 2) of Hedt-I, Hedt-II, Hedt-III, Hedt-IV, RhamI, Rham-II, Isor, Tddf and Pach formed strong deprotonated ions $[\mathrm{M}-\mathrm{H}]^{-}$at $m / z 301,463,595,727,491,635,477,329$ and 343 , respectively. The adduct ion $[\mathrm{M}+\mathrm{HCOOH}-\mathrm{H}]^{-}$of Httf was more abundant than the corresponding deprotonated ions $[\mathrm{M}-\mathrm{H}]^{-}$, thus $[\mathrm{M}+\mathrm{HCOOH}-\mathrm{H}]^{-}$at $m / z 551$ was monitored for Httf. Typical SIM chromatograms of the 10 flavonoids in $V$. coloratum extracts had well-formed and fully separated peaks (Fig. 2). The compounds were identified by comparing their retention times and mass spectra with those of the pure isolated compounds.

Extraction Procedure Reflux and ultrasonication (all with methanol as extractants) were used to extract the marker constituents in $V$. coloratum and all the procedures were repeated twice. The results indicated that the extraction yield from reflux was markedly higher than from ultrasonication. Therefore, in this study, we used reflux extraction for the 10 flavonoids.

In order to obtain optimal extraction efficiency, different extraction solvents $(10 \%, 30 \%, 50 \%, 70 \%, 100 \%$ methanol aqueous solutions $(\mathrm{v} / \mathrm{v})$ and extraction times $(10,30,60$, $120 \mathrm{~min}$ ) were tried. The results showed that the solvent containing 50\% methanol had better extraction efficiency and produced fewer background peaks. In addition, the 10 flavonoids could be completely extracted within $30 \mathrm{~min}$.

Method Validation. Calibration Curves, Limits of Quantification and Matrix Effects Standard stock solutions were prepared as described in 'Preparation of Standard Solutions' and diluted to appropriate concentrations to establish the calibration curves. At least seven different concentrations were used, and the calibration curves were then constructed by plotting the peak area versus the concentration of each analyte. The calculated results are given in Table 2 . The correlation coefficients were all greater than 0.999 except for Rham-II and Pach, indicating a high degree of linearity.

The limit of quantification (LOQ) was calculated as the amount of the injected analyte which gave a signal-to-noise ratio of 10 . The LOQ values of the method for the 10 flavonoids are also listed in Table 2.

To evaluate the matrix effect, a sample of $V$. coloratum (No. 14) was extracted as described in 'Preparation of Sample Solutions' and $1 \mathrm{ml}$ of this solution was spiked with $1 \mathrm{ml}$ of a standard mixture solution with a known concentration, while another $1 \mathrm{ml}$ of sample solution was diluted to $2 \mathrm{ml}$ with $50 \%$ methanol. The standard solution was also diluted with an equal volume of $50 \%$ methanol and analyzed. The corresponding peak areas of the analytes in the standard spiked sample solutions $(A)$ minus those in sample solutions $(B)$ were then compared with those of the standard solutions (C). The ratio $[(A-B) / C \times 100 \%]$ was defined as the matrix

Table 2. Summary of the Method Validation of 10 Flavonoids in V. coloratum

\begin{tabular}{|c|c|c|c|c|c|c|c|}
\hline $\begin{array}{c}\text { Marker } \\
\text { component }\end{array}$ & $\begin{array}{l}\text { Retention } \\
\text { times (min) }\end{array}$ & $\begin{array}{l}\text { Quantitation ion } \\
\qquad(\mathrm{m} / z)\end{array}$ & $\begin{array}{c}\text { Regression } \\
\text { equation }\end{array}$ & $r^{2}$ & $\begin{array}{l}\text { Linear range } \\
\qquad(\mu \mathrm{g} / \mathrm{ml})\end{array}$ & $\begin{array}{c}\text { LOQ } \\
(\mu \mathrm{g} / \mathrm{ml})\end{array}$ & $\begin{array}{c}\text { Matrix } \\
\text { effect }(\%)\end{array}$ \\
\hline Hedt-I & 31.675 & $301.15[\mathrm{M}-\mathrm{H}]^{-}$ & $y=9.43 \times 10^{5} x+1.02 \times 10^{5}$ & 0.9997 & $0.149-8.940$ & 0.030 & 104.4 \\
\hline Hedt-II & 17.250 & $463.30[\mathrm{M}-\mathrm{H}]^{-}$ & $y=4.55 \times 10^{4} x-0.76 \times 10^{4}$ & 0.9991 & $0.230-13.80$ & 0.105 & 98.8 \\
\hline Hedt-III & 16.245 & $595.20[\mathrm{M}-\mathrm{H}]^{-}$ & $y=7.31 \times 10^{4} x+0.82 \times 10^{4}$ & 0.9994 & $5.000-300.0$ & 0.050 & 97.6 \\
\hline Hedt-IV & 14.316 & $727.35[\mathrm{M}-\mathrm{H}]^{-}$ & $y=3.53 \times 10^{4} x-0.68 \times 10^{4}$ & 1.0000 & $0.835-125.3$ & 0.104 & 101.9 \\
\hline Rham-I & 34.316 & $491.10[\mathrm{M}-\mathrm{H}]^{-}$ & $y=8.80 \times 10^{4} x-0.22 \times 10^{4}$ & 0.9992 & $0.064-3.840$ & 0.006 & 99.6 \\
\hline Rham-II & 35.733 & $635.20[\mathrm{M}-\mathrm{H}]^{-}$ & $y=6.17 \times 10^{3} x+1.61 \times 10^{3}$ & 0.9989 & $1.435-86.10$ & 0.720 & 98.0 \\
\hline Isor & 25.858 & $477.25[\mathrm{M}-\mathrm{H}]^{-}$ & $y=2.70 \times 10^{4} x+0.67 \times 10^{4}$ & 0.9999 & $0.930-55.80$ & 0.093 & 98.2 \\
\hline $\mathrm{Httf}$ & 35.260 & $551.20[\mathrm{M}+\mathrm{HCOOH}-\mathrm{H}]^{-}$ & $y=5.20 \times 10^{4} x+0.02 \times 10^{4}$ & 0.9990 & $0.067-4.020$ & 0.007 & 100.1 \\
\hline Tddf & 38.341 & $329.10[\mathrm{M}-\mathrm{H}]^{-}$ & $y=7.84 \times 10^{4} x-0.15 \times 10^{4}$ & 0.9994 & $0.270-16.20$ & 0.054 & 98.0 \\
\hline Pach & 44.213 & $343.15[\mathrm{M}-\mathrm{H}]^{-}$ & $y=3.47 \times 10^{5} x-0.31 \times 10^{5}$ & 0.9986 & $0.110-6.600$ & 0.110 & 100.5 \\
\hline
\end{tabular}

$y$ peak area, $x$ concentration of the compounds $(\mu \mathrm{g} / \mathrm{ml}), r^{2}$ correlation coefficient of the equation, LOQ limit of quantification.

Table 3. Results of Intra- and Inter-Day Precisions for 10 Flavonoids

\begin{tabular}{|c|c|c|c|c|c|}
\hline \multirow{2}{*}{$\begin{array}{c}\text { Marker } \\
\text { component }\end{array}$} & \multirow{2}{*}{$\begin{array}{c}\text { Theoretical } \\
\text { concentration }(\mu \mathrm{g} / \mathrm{ml})\end{array}$} & \multicolumn{2}{|c|}{ Intra-day $(n=6)$} & \multicolumn{2}{|c|}{ Inter-day $(n=18)$} \\
\hline & & Detected $(\mu \mathrm{g} / \mathrm{ml})$ & RSD \% & Detected $(\mu \mathrm{g} / \mathrm{ml})$ & RSD \% \\
\hline Hedt-I & 1.490 & $1.512 \pm 0.011$ & 0.7 & $1.486 \pm 0.064$ & 4.3 \\
\hline Hedt-II & 2.300 & $2.317 \pm 0.106$ & 4.6 & $2.324 \pm 0.029$ & 1.2 \\
\hline Hedt-III & 50.00 & $49.41 \pm 1.464$ & 3.0 & $49.33 \pm 0.030$ & 0.6 \\
\hline Hedt-IV & 20.88 & $20.48 \pm 0.296$ & 1.4 & $20.30 \pm 0.443$ & 2.2 \\
\hline Rham-I & 0.640 & $0.633 \pm 0.026$ & 4.0 & $0.632 \pm 0.015$ & 2.3 \\
\hline Rham-II & 14.35 & $14.31 \pm 0.431$ & 3.0 & $14.43 \pm 0.258$ & 1.8 \\
\hline Isor & 9.300 & $9.253 \pm 0.128$ & 1.4 & $9.277 \pm 0.154$ & 1.7 \\
\hline Httf & 0.670 & $0.644 \pm 0.017$ & 2.7 & $0.651 \pm 0.026$ & 4.0 \\
\hline Tddf & 2.700 & $2.654 \pm 0.104$ & 3.9 & $2.628 \pm 0.061$ & 2.3 \\
\hline Pach & 1.100 & $1.071 \pm 0.044$ & 4.1 & $1.084 \pm 0.027$ & 2.5 \\
\hline
\end{tabular}


effect. The matrix effects of 10 flavonoids were ranged from 97.6 to $104.4 \%$ (Table 2), and these indicated that there were no significant matrix effects.

Precision Intra-day precision was examined by analyzing the standard solution within one day, and inter-day precision was determined on three independent days. The relative standard deviation (R.S.D.) was calculated as a measurement of method precision. The intra-day and inter-day precisions of the determination of the 10 flavonoids were not more than $4.6 \%$ and $4.3 \%$. The results are shown in Table 3 .

Recoveries The recoveries of the 10 flavonoids were determined by the standard addition method. Three concentrations (low, medium, high) of the mixed standard solutions were spiked with known amounts of $V$. coloratum sample (No. 14). Then, the resultant samples were extracted and analyzed by the proposed method and triplicate experiments were carried out at each level. The total detected amounts $\left(A^{\prime}\right)$ minus the original amounts $\left(B^{\prime}\right)$ were then compared with the added amounts $\left(C^{\prime}\right)$. The ratio $\left[\left(A^{\prime}-B^{\prime}\right) / C^{\prime} \times 100 \%\right]$ was defined as the recovery. As shown in Table 4 , the recoveries of the 10 flavonoids ranged from 93.4 to $103.9 \%$, with an R.S.D. of no more than $4.7 \%$. Considering the results of the recovery test, the method was considered to be accurate.

Repeatability and Stability Six individual samples from the same batch (No. 14) were extracted and analyzed by the proposed method. The R.S.D. value was calculated as a measurement of method repeatability. The R.S.D. values of the 10 compounds in these samples were not more than $5.1 \%$, which showed the high repeatability of the method. Stability was tested with a standard solution and a sample so-
Table 4. Recoveries of 10 Flavonoids in V. coloratum $(n=9)$

\begin{tabular}{|c|c|c|c|c|c|c|}
\hline $\begin{array}{c}\text { Marker } \\
\text { component }\end{array}$ & $\begin{array}{c}\text { Detected } \\
\text { amount } \\
(\mu \mathrm{g})\end{array}$ & $\begin{array}{c}\text { Original } \\
\text { amount } \\
(\mu \mathrm{g})\end{array}$ & $\begin{array}{c}\text { Added } \\
\text { amount } \\
(\mu \mathrm{g})\end{array}$ & $\begin{array}{c}\text { Recoveries } \\
(\%)\end{array}$ & $\begin{array}{c}\text { Mean } \pm \text { S.D. } \\
(\%)\end{array}$ & $\begin{array}{l}\text { RSD } \\
(\%)\end{array}$ \\
\hline \multirow[t]{3}{*}{ Hedt-I } & 100.8 & 65.00 & 37.25 & 96.1 & $98.7 \pm 2.9$ & 3.0 \\
\hline & 140.9 & & 74.50 & 101.9 & & \\
\hline & 174.5 & & 111.8 & 98.0 & & \\
\hline \multirow[t]{3}{*}{ Hedt-II } & 179.6 & 113.0 & 69.00 & 96.4 & $98.9 \pm 2.5$ & 2.5 \\
\hline & 249.3 & & 138.0 & 98.8 & & \\
\hline & 322.8 & & 207.0 & 101.4 & & \\
\hline \multirow[t]{3}{*}{ Hedt-III } & 2976 & 1970 & 1000 & 100.6 & $100.4 \pm 0.4$ & 0.4 \\
\hline & 3983 & & 2000 & 100.7 & & \\
\hline & 4968 & & 3000 & 99.9 & & \\
\hline \multirow[t]{3}{*}{ Hedt-IV } & 2838 & 1862 & 939.6 & 103.9 & $99.4 \pm 3.9$ & 4.0 \\
\hline & 3677 & & 1879 & 96.6 & & \\
\hline & 4613 & & 2819 & 97.6 & & \\
\hline \multirow[t]{3}{*}{ Rham-I } & 10.30 & 5.500 & 4.800 & 99.4 & $99.1 \pm 3.0$ & 3.1 \\
\hline & 14.70 & & 9.600 & 95.9 & & \\
\hline & 20.20 & & 14.40 & 102.0 & & \\
\hline \multirow{3}{*}{ Rham-II } & 299.9 & 195.5 & 100.5 & 103.9 & $100.9 \pm 3.5$ & 3.5 \\
\hline & 399.9 & & 200.9 & 101.7 & & \\
\hline & 488.0 & & 301.4 & 97.1 & & \\
\hline \multirow[t]{3}{*}{ Isor } & 293.9 & 204.0 & 93.00 & 96.7 & $98.6 \pm 2.9$ & 3.0 \\
\hline & 393.7 & & 186.0 & 102.0 & & \\
\hline & 475.1 & & 279.0 & 97.2 & & \\
\hline \multirow[t]{3}{*}{ Httf } & 3.000 & 2.000 & 1.005 & 100.8 & $100.8 \pm 1.6$ & 1.6 \\
\hline & 4.100 & & 2.010 & 102.4 & & \\
\hline & 5.000 & & 3.015 & 99.3 & & \\
\hline \multirow[t]{3}{*}{ Tddf } & 93.40 & 62.50 & 32.40 & 95.5 & $98.8 \pm 3.4$ & 3.5 \\
\hline & 128.8 & & 64.80 & 102.3 & & \\
\hline & 158.4 & & 97.20 & 98.7 & & \\
\hline \multirow[t]{3}{*}{ Pach } & 35.30 & 24.00 & 11.00 & 102.6 & $98.0 \pm 4.6$ & 4.7 \\
\hline & 44.60 & & 22.00 & 93.4 & & \\
\hline & 56.40 & & 33.00 & 98.1 & & \\
\hline
\end{tabular}

Table 5. Contents of 10 Flavonoids in V. coloratum Grown on Different Host Species and Different Sources (mg/g)

\begin{tabular}{|c|c|c|c|c|c|c|c|c|c|c|c|c|c|}
\hline No. & Host species & Sources & Hedt-I & Hedt-II & Hedt-III & Hedt-IV & Rham-I & Rham-II & Isor & Httf & Tddf & Pach & $\begin{array}{c}\text { Total } \\
\text { amounts }\end{array}$ \\
\hline 1 & Populus ussuriensis Kом. ${ }^{\wedge} \triangle$ & $\mathrm{CBM}$ & 0.113 & 0.073 & 1.462 & 0.039 & 0.007 & 0.047 & 0.021 & N.D. & 0.041 & 0.018 & 1.821 \\
\hline 2 & Populus ussuriensis Ком. $\triangle{ }^{\Delta}$ & CBM & 0.013 & 0.092 & 5.813 & 0.182 & 0.008 & 0.563 & 0.474 & N.D. & 0.016 & 0.012 & 7.173 \\
\hline 3 & Populus ussuriensis Kом. ${ }^{\Delta} \triangle$ & CBM & 0.156 & 0.195 & 1.962 & 0.429 & 0.008 & 0.067 & 0.037 & N.D. & 0.048 & 0.018 & 2.920 \\
\hline 4 & Ulmus pumila L.. & CBM & 0.041 & 0.070 & 1.568 & 3.906 & 0.020 & 0.434 & 0.142 & 0.006 & 0.046 & 0.013 & 6.245 \\
\hline 5 & Ulmus pumila L.A & CBM & 0.012 & 0.060 & 2.244 & 3.923 & 0.004 & 0.256 & 0.258 & N.D. & 0.057 & 0.023 & 6.837 \\
\hline 6 & Ulmus pumila L.A & CBM & 0.005 & 0.037 & 2.464 & 4.670 & 0.005 & 0.271 & 0.188 & N.D. & 0.035 & 0.017 & 7.692 \\
\hline 7 & Ulmus pumila L.` & CBM & 0.028 & 0.088 & 3.918 & 0.183 & 0.014 & 0.340 & 0.121 & 0.003 & 0.044 & 0.022 & 4.760 \\
\hline 8 & Tilia amurensis RuPR. & CBM & 0.013 & 0.080 & 5.558 & 0.128 & 0.005 & 0.437 & 0.147 & 0.002 & 0.032 & 0.016 & 6.417 \\
\hline 9 & Tilia amurensis RuPR. ${ }^{\boldsymbol{\Delta}}$ & CBM & 0.129 & 0.110 & 3.148 & 1.151 & 0.015 & 0.163 & 0.155 & 0.003 & 0.100 & 0.032 & 5.006 \\
\hline 10 & Tilia amurensis RuPR. ${ }^{\Delta} \triangle$ & CBM & 0.040 & 0.027 & 1.558 & 3.385 & 0.004 & 0.352 & 0.232 & N.D. & 0.019 & 0.014 & 5.631 \\
\hline 11 & Betula platyphylla SuK. & $\mathrm{CBM}$ & 0.008 & 0.049 & 6.252 & 0.149 & 0.009 & 0.515 & 0.174 & 0.002 & 0.053 & 0.018 & 7.227 \\
\hline 12 & Betula platyphylla SuK. & $\mathrm{CBM}$ & 0.011 & 0.046 & 1.291 & 2.538 & 0.006 & 0.245 & 0.073 & N.D. & 0.011 & 0.008 & 4.230 \\
\hline 13 & Pyrus ussuriensis МАХІм. & CBM & 0.026 & 0.093 & 3.911 & 0.055 & 0.005 & 0.231 & 0.211 & 0.003 & 0.057 & 0.029 & 4.621 \\
\hline 14 & Acer monm Махім. & $\mathrm{CBM}$ & 0.130 & 0.226 & 3.940 & 3.724 & 0.011 & 0.391 & 0.408 & 0.004 & 0.125 & 0.048 & 9.007 \\
\hline 15 & $\begin{array}{l}\text { Syrigu reticulata (BLuME) } \\
\text { HARA var. mandshurica }\end{array}$ & $\mathrm{CBM}$ & 0.018 & 0.096 & 2.160 & 1.419 & 0.006 & 0.553 & 0.264 & N.D. & 0.023 & 0.015 & 4.554 \\
\hline 16 & Populus ussuriensis Kом. ${ }^{\triangle}$ & QM & 0.063 & 0.177 & 2.136 & 0.018 & 0.005 & 0.079 & 0.240 & 0.003 & 0.018 & 0.009 & 2.748 \\
\hline 17 & Populus ussuriensis Kом. ${ }^{\triangle}$ & QM & 0.026 & 0.248 & 4.958 & 0.340 & 0.025 & 1.258 & 0.494 & 0.005 & 0.062 & 0.014 & 7.426 \\
\hline 18 & Populus ussuriensis Kом. ${ }^{\triangle}$ & XYT & 0.126 & 0.099 & 2.849 & 1.082 & 0.014 & 0.152 & 0.143 & 0.003 & 0.097 & 0.033 & 4.598 \\
\hline 19 & Populus ussuriensis Ком. ${ }^{\triangle}$ & $\mathrm{XYT}$ & 0.106 & 0.075 & 2.049 & 1.056 & 0.009 & 0.172 & 0.191 & 0.002 & 0.055 & 0.013 & 2.758 \\
\hline 20 & Populus ussuriensis Kом. ${ }^{\triangle}$ & CISR & 0.003 & 0.044 & 0.648 & 0.021 & 0.005 & 0.028 & 0.036 & N.D. & 0.006 & 0.005 & 0.796 \\
\hline 21 & Populus ussuriensis Ком. ${ }^{\triangle}$ & CISR & 0.007 & 0.048 & 0.834 & 0.018 & 0.004 & 0.068 & 0.062 & N.D. & 0.012 & 0.005 & 1.058 \\
\hline 22 & Populus ussuriensis Ком. ${ }^{\triangle}$ & CISR & 0.040 & 0.022 & 0.933 & 0.022 & 0.004 & 0.111 & 0.036 & N.D. & 0.015 & 0.007 & 1.190 \\
\hline 23 & Populus ussuriensis Ком. ${ }^{\triangle}$ & CISR & 0.070 & 0.012 & 2.278 & 0.044 & 0.025 & 0.633 & 0.316 & 0.002 & 0.026 & 0.008 & 3.414 \\
\hline 24 & Ulmus pumila $\mathrm{L}$ & CISR & 0.040 & 0.018 & 1.452 & 0.044 & 0.005 & 0.304 & 0.027 & N.D. & 0.004 & 0.005 & 1.899 \\
\hline 25 & Salix babylonica L. & CISR & 0.013 & 0.039 & 2.829 & 0.030 & 0.003 & 0.127 & 0.124 & N.D. & 0.039 & 0.022 & 3.226 \\
\hline 26 & Populus ussuriensis Ком. ${ }^{\triangle}$ & DQM & 0.012 & 0.053 & 2.749 & 3.382 & 0.005 & 0.962 & 0.125 & 0.003 & 0.052 & 0.029 & 7.372 \\
\hline 27 & Populus ussuriensis Ком. ${ }^{\triangle}$ & DQM & 0.004 & 0.032 & 1.854 & 2.387 & 0.007 & 0.439 & 0.109 & N.D. & 0.015 & 0.009 & 4.855 \\
\hline 28 & Melia azedrach $\mathrm{L}$. & XXM & 0.001 & 0.013 & 0.232 & 0.085 & 0.048 & 0.133 & 0.159 & 0.102 & 0.049 & 0.092 & 0.914 \\
\hline 29 & Melia azedrach L. & XXM & N.D. & 0.012 & 0.089 & 0.082 & 0.017 & 0.047 & 0.039 & 0.013 & 0.060 & 0.060 & 0.419 \\
\hline 30 & Melia azedrach L. & XXM & N.D. & 0.016 & 0.288 & 0.034 & 0.047 & 0.143 & 0.192 & 0.028 & 0.149 & 0.188 & 1.085 \\
\hline
\end{tabular}

N.D.: Lower than LOQ; CBM: Changbai Mountain, QM: Qian Mountain, XYT: Xiyue temple, CISR: Chengde Imperial Summer Resort, DQM: Da Qing Mountain, XXM: Xianxia Mounain. $\triangle \mathrm{A}$ group, $\triangle \mathrm{B}$ group. 
Table 6. Summary of A Group (Same Source: CBM, Different Host Species: No. 1-12) ANOVA Results

\begin{tabular}{|c|c|c|c|c|c|c|c|c|c|c|c|c|c|}
\hline $\begin{array}{c}\text { Marker } \\
\text { component }\end{array}$ & $\begin{array}{c}\text { Sources of } \\
\text { variation }\end{array}$ & SS & $\mathrm{df}$ & MS & $F$ & Sig. & $\begin{array}{c}\text { Marker } \\
\text { component }\end{array}$ & $\begin{array}{c}\text { Sources of } \\
\text { variation }\end{array}$ & SS & $\mathrm{df}$ & MS & $F$ & Sig. \\
\hline \multirow[t]{3}{*}{ Hedt-I } & Between groups & 0.013 & 3 & 0.004 & 1.775 & 0.229 & Rham-II & Between groups & 0.032 & 3 & 0.011 & 0.322 & 0.810 \\
\hline & Within groups & 0.019 & 8 & 0.002 & & & & Within groups & 0.266 & 8 & 0.033 & & \\
\hline & Total & 0.032 & 11 & & & & & Total & 0.299 & 11 & & & \\
\hline \multirow[t]{3}{*}{ Hedt-II } & Between groups & 0.008 & 3 & 0.003 & 1.590 & 0.266 & Isor & Between groups & 0.005 & 3 & 0.002 & 0.085 & 0.966 \\
\hline & Within groups & 0.014 & 8 & 0.002 & & & & Within groups & 0.153 & 8 & 0.019 & & \\
\hline & Total & 0.022 & 11 & & & & & Total & 0.158 & 11 & & & \\
\hline \multirow[t]{3}{*}{ Hedt-III } & Between groups & 2.429 & 3 & 0.810 & 0.187 & 0.902 & Tddf & Between groups & 0.001 & 3 & 0.000 & 0.294 & 0.829 \\
\hline & Within groups & 34.692 & 8 & 4.336 & & & & Within groups & 0.005 & 8 & 0.001 & & \\
\hline & Total & 37.121 & 11 & & & & & Total & 0.006 & 11 & & & \\
\hline \multirow[t]{3}{*}{ Hedt-IV } & Between groups & 15.561 & 3 & 5.187 & 1.999 & 0.193 & Pach & Between groups & 0.000 & 3 & 0.000 & 0.668 & 0.595 \\
\hline & Within groups & 20.761 & 8 & 2.595 & & & & Within groups & 0.000 & 8 & 0.000 & & \\
\hline & Total & 36.322 & 11 & & & & & Total & 0.000 & 11 & & & \\
\hline \multirow[t]{3}{*}{ Rham-I } & Between groups & 0.000 & 3 & 0.000 & 0.256 & 0.855 & Total & Between groups & 10.339 & 3 & 3.446 & 1.059 & 0.419 \\
\hline & Within groups & 0.000 & 8 & 0.000 & & & amounts & Within groups & 26.043 & 8 & 3.255 & & \\
\hline & Total & 0.000 & 11 & & & & & Total & 36.383 & 11 & & & \\
\hline
\end{tabular}

The content of Httf was too low to allow statistical analysis.

Table 7. Summary of B Group (Same Host Species: Populus ussuriensis Kom., Different Sources: No. 1-3, No. 16-23, No. 26-27) ANOVA Results

\begin{tabular}{|c|c|c|c|c|c|c|c|c|c|c|c|c|c|}
\hline $\begin{array}{c}\text { Marker } \\
\text { component }\end{array}$ & $\begin{array}{c}\text { Sources of } \\
\text { variation }\end{array}$ & SS & $\mathrm{df}$ & MS & $F$ & Sig. & $\begin{array}{c}\text { Marker } \\
\text { component }\end{array}$ & $\begin{array}{c}\text { Sources of } \\
\text { variation }\end{array}$ & SS & $\mathrm{df}$ & MS & $F$ & Sig. \\
\hline \multirow[t]{3}{*}{ Hedt-I } & Between groups & 0.013 & 3 & 0.004 & 2.150 & 0.182 & Rham-II & Between groups & 0.357 & 3 & 0.119 & 0.752 & 0.555 \\
\hline & Within groups & 0.015 & 7 & 0.002 & & & & Within groups & 1.108 & 7 & 0.158 & & \\
\hline & Total & 0.028 & 10 & & & & & Total & 1.465 & 10 & & & \\
\hline \multirow[t]{3}{*}{ Hedt-II } & Between groups & 0.046 & 3 & 0.015 & 8.632 & 0.009 & Isor & Between groups & 0.088 & 3 & 0.029 & 0.929 & 0.475 \\
\hline & Within groups & 0.012 & 7 & 0.002 & & & & Within groups & 0.221 & 7 & 0.032 & & \\
\hline & Total & 0.058 & 10 & & & & & Total & 0.309 & 10 & & & \\
\hline \multirow[t]{3}{*}{ Hedt-III } & Between groups & 10.018 & 3 & 3.339 & 1.351 & 0.333 & Tddf & Between groups & 0.005 & 3 & 0.002 & 4.478 & 0.047 \\
\hline & Within groups & 17.308 & 7 & 2.473 & & & & Within groups & 0.003 & 7 & 0.000 & & \\
\hline & Total & 27.326 & 10 & & & & & Total & 0.008 & 10 & & & \\
\hline \multirow[t]{3}{*}{ Hedt-IV } & Between groups & 1.532 & 3 & 0.511 & 27.407 & 0.000 & Pach & Between groups & 0.000 & 3 & 0.000 & 3.968 & 0.061 \\
\hline & Within groups & 0.130 & 7 & 0.019 & & & & Within groups & 0.000 & 7 & 0.000 & & \\
\hline & Total & 1.663 & 10 & & & & & Total & 0.001 & 10 & & & \\
\hline \multirow[t]{3}{*}{ Rham-I } & Between groups & 0.000 & 3 & 0.000 & 0.307 & 0.820 & Total & Between groups & 19.374 & 3 & 6.458 & 1.369 & 0.328 \\
\hline & Within groups & 0.001 & 7 & 0.000 & & & amounts & Within groups & 33.013 & 7 & 4.716 & & \\
\hline & Total & 0.001 & 10 & & & & & Total & 52.386 & 10 & & & \\
\hline
\end{tabular}

The content of Httf was too low to allow statistical analysis.

lution that were stored at room temperature and analyzed every $12 \mathrm{~h}$ over $3 \mathrm{~d}$, and the analytes were found to be stable over 72 h (R.S.D. $<5 \%$ ).

Sample Assay The optimized chromatographic method was used to determinate the 10 flavonoids in $V$. coloratum. In Fig. 2, the peaks of the 10 flavonoids showed that the separations were good. The contents of the 10 flavonoids in $\mathrm{V}$. coloratum samples growing on different host species and at different sources are summarized in Table 5. The predominant compounds in all examined samples were Hedt-III and Hedt$\mathrm{IV}$, which ranged from 6.252 to $0.089 \mathrm{mg} / \mathrm{g}$ and from 4.670 to $0.018 \mathrm{mg} / \mathrm{g}$, respectively. These results correspond to the pharmacological investigation of Shanghai mistletoe Group. ${ }^{4)}$ They found that the dihydroflavones contribute in cardiovascular diseases treatment. Wang et al. have reported an HPLC method for the simultaneous determination of 4 flavonoids (Hedt-I, Tddf, Pach and ombuine) in V. coloratum. ${ }^{21)}$ However, the detectable contents were low in comparison with our results. The discrepancy could be a result of the complex extraction method as to cause the loss of flavonoids.

In order to evaluate $V$. coloratum-host-source interactions, one-way analysis of variance was performed on the A group (same source: CBM, different host species: No. 1-3, Populus ussuriensis Koм.; No. 4-7, Ulmus pumila L.; No. 810, Tilia amurensis Rupr.; No. 11-12, Betula platyphylla Suk.) and the B group (same host species: Populus ussuriensis Kom., different sources: No. 1-3, CBM; No. 16-17, QM; No. 18-19, XYT; No. 20-23, CISR; No. 26-27, DQM), respectively. The results from the A group (Table 6) showed that there was no significant difference among samples, while in the B group (Table 7), 3 of the 10 individual flavonoids level varied significantly at $p \leq 0.05$. Therefore, compared with the host species, the sample source has a significant impact on the sample content. In short, the host species was not the main factor in affecting the quality of $V$. coloratum. The reason for this may be that $V$. coloratum is semi-parasitic plant and can photosynthesizes itself. $V$. coloratum only acquires mineral nutrition and water from their host through a root connection. This could explain why the ancient medical textbooks and Chinese pharmacopoeias do not give details of the host of $V$. coloratum. As far as flavonoids are concerned, we proposed that $V$. coloratum could be used directly as a medicine without knowledge of the host species. 


\section{Conclusion}

A novel sensitive and selective HPLC-MS method was developed and validated to simultaneously determine 10 flavonoids from $V$. coloratum grown on different host species and different sources. A one-way analysis of variance was used to evaluate $V$. coloratum-host-source interactions. In accounting the contents of flavonoids, the source of $V$. coloratum could be a significant impact on the sample content. In contrast, the host did not play significant role on the chemical composition. Here, we proposed that $V$. coloratum could be used directly as a medicine without knowledge of the host species.

Acknowledgements This work was partly supported by the National Natural Science Foundation of China (Grant No. 30901967). We are thankful to the Scientific Research Foundation for the doctor of the Liaoning Provincial Department of Science and Technology (Grant No. 20091078) and the Science and Technology Research Projects of the Educational Commission of Liaoning Province (Grant Nos. 2009A684 and 2008T187) for financial support. We are also thankful for the postdoctoral workstation of Pharmaland Technology Development Co., Ltd.

\section{References}

1) China Pharmacopoeia Committee, "Pharmacopoeia of the People's Republic of China," Vol. 1, China Medical Science and Technology Press, Beijing, 2010.

2) Leu Y. L., Hwang T. L., Chung Y. M., Hong P. Y., Chem. Pharm. Bull., 54, 1063-1066 (2006).

3) Chui S. T., "Proceedings of International Symposium on Plant Biodiversity and Development of Bioactive Natural Products," Taichung, Nov. 18-20, Taiwan, 2001, pp. 103-116.

4) Shanghai mistletoe Group, Acta Pharmacol. Sin., 3, 39-54 (1977).

5) Li X. L., Feng P., Qian Y., Dong K., Liu S. J., Wang X. J., Chinese Journal of Integrated Tradition and Western Medicine on Liver Diseases, 18, 229-231 (2008).

6) Zhou D. M., Qin Z. H., China Patent ZL9611919.5 (1997).

7) Papp I., Apáti P., Andrasek V., Blázovics A., Balázs A., Kursinszki L., Kite G. C., Houghton P. J., Kéry Á., Chromatographia, 60, 93-100 (2004).

8) Luczkiewicz M., Cisowski W., Kaiser P., Ochocka R., Piotrowski A., Acta Pol. Pharm., 58, 373-379 (2001).

9) Wang J., Wang G. J., Yan H., Zhu Y. L., Lishizhen Medicine and Mate- ria Medica Research, 4, 300-303 (2005).

10) Hayashi S., Miyamoto E., Kudo K., Kameoka H., Hanafusa M., J. Essent. Oil Res., 8, 619-626 (1996).

11) Chu W. F., Qiao G. F., Bai Y. L., Pan Z. W., Li G. Y., Piao X. M., Wu L., Lu Y. J., Yang B. F., Phytother. Res., 22, 134-137 (2008).

12) Xu C. G., Zhang M. H., Li T. Y., Guo N. J., Guan Z. W., Acta Academiae Medicine Shandong, 35, 313-316 (1997).

13) Guan Z. W., Liu X. H., Liu H. X., Cui Y. X., J. Chin. Pharm. Sci., 2, $73-79(2000)$

14) Yao H., Liao Z. X., Wu Q., Lei G. Q., Liu Z. J., Chen D. F., Chen J. K., Zhou T. S., Chem. Pharm. Bull., 54, 133-135 (2006).

15) Mori A., Nishino C., Enoki N., Tawata S., Phytochemistry, 26, 1017 1020 (1988).

16) Garo E., Maillard M., Antus S., Mavi S., Hostettmann K., Phytochemistry, 43, 1265-1269 (1996).

17) Al-Dabbas M. M., Al-Ismail K., Abu-Taleb R., Hashimoto F., Rabah I. O., Kitahara K., Fujita K., Suganuma T., Chem. Nat. Compd., 47, 1721 (2011)

18) Zhang G. W., Ma X. Q., Su J. W., Zeng L. H., Wang F. S., Yang D. P., Chin. Tradit. Herbal Drugs, 32, 871-874 (2001).

19) Ishitsuka H., Shirai H., Umeda I., Suhara Y., Eur. Pat. Appl., 32 (1980).

20) Bencheraiet R., Kherrab H., Kabouche A., Kabouche Z., Jay M., Rec. Nat. Prod., 5, 52-55 (2011).

21) Wang X. Y., Yu Z. G., Gao X. X., Song S., Li Y. H., Zhao Y. L., Chin. Tradit. Herbal Drugs, 41, 135-137 (2010).22.

22) Wang Y. H., Strait Pharm. J., 19, 84-85 (2007).

23) Zhao Y. L., Ma M. Y., Gao X. X., Liu T., Yu Z. G., Bi K. S., Chin. J. Chromatogr., 24, 479-481 (2006).

24) Bao K.-D., Li P., Qi L.-W., Li H.-J., Yi L., Wang W., Wang Y.-Q., Chem. Pharm. Bull., 57, 144-148 (2009).

25) Sun Y. Q., Liu K., Zhang Z. X., J. Chin. Med. Mat., 23, 29-30 (2000).

26) Kong D. Y., Luo S. Q., Li H. T., Lei X. H., Acta Pharmacol. Sin., 9 , 707-710 (1988)

27) Kong D. Y., Luo S. Q., Li H. T., Lei X. H., Acta Pharmacol. Sin., 8, 593-600 (1988).

28) Wagner H., Chari V. M., Sonnenbichler J., Tetrahedron Lett., 21 , 1799-1802 (1976).

29) Itokawa H., Suto K., Takeya K., Chem. Pharm. Bull., 29, 254-256 (1981).

30) Kumari G. N. K., Rao L. J. M., Rao N. S. P., Proc. Indian Acad. Sci. (Chem. Sci.), 97, 171-176 (1986). 